\title{
PERANAN GAYA KEPEMIMPINAN SITUASIONAL DALAM MENINGKATKAN KINERJA PEGAWAI PUSAT PENGEMBANGAN SUMBER DAYA MANUSIA APARATUR (PPSDMA)
}

\author{
Roni Rahmat Nugraha \\ Pusat Pengembangan Sumberdaya manusia Aparatur \\ Email: ronirahmatnugraha@esdm.go.id
}

\begin{abstract}
ABSTRAK
Pada setiap organisasi, baik lembaga pemerintah maupun swasta, peranan manusia sangatlah dominan untuk menjalankan tujuan organisasi. Dalam melakukan kegiatan menggerakan atau memberikan motivasi kepada bawahannya, berbagai cara dapat dilakukan oleh seorang pemimpin melalui tindakantindakan yang selalu terarah pada pencapaian tujuan organisasi. Berbagai tipe dan gaya kepemimpinan banyak dijumpai dalam kehidupan sehari-hari. Tujuan penelitian ini adalah untuk mengetahui apakah ada pengaruh gaya kepemimpinan situasional terhadap kinerja pegawai? Model gaya kepemimpinan situasional dipilih karena gaya ini pendekatannya lebih difokuskan terhadap motif perilaku dan tingkat kematangan pengikut (follower) terhadap tugas pada organisasi dan bersifat fleksibel sehingga dianggap sebagai gaya kepemimpinan yang efektif. Penelitian ini dilakukan pada Pusat Pengembangan Sumber Daya Manusia Aparatur (PPSDMA) Kementerian Energi dan Sumber Daya Mineral tahun 2017. Data yang digunakan adalah data primer dengan metode survey dan data sekunder dari hasil studi literatur yang terkait. Pengolahan data menggunakan metode statistik analisis regresi linear berganda untuk mengetahui hubungan pengaruh gaya kepemimpinan situasional terhadap kinerja pegawai. Hasil penelitian menunjukkan bahwa secara simultan, variabel gaya kepemimpinan situasional akan berpengaruh terhadap variabel kinerja. Hasil analisis data penelitian diketahui adanya pengaruh variabel kepemimpinan situasional terhadap variabel kinerja sebesar $84,5 \%$, sedangkan $15,5 \%$ lainnya dipengaruhi oleh variabel lain yang belum masuk dalam penelitian ini. Gaya kepemimpinan situasional, yakni directing, selling, telling, participating, dan delegating dapat disimpulkan sesuai untuk diterapkan di PPSDMA, namun yang paling dominan adalah sellling dan participating.
\end{abstract}

Kata Kunci: Gaya Kepemimpinan Situasional, Kinerja Pegawai

\begin{abstract}
In every organization, both government and private institutions, the role of humans is very dominant in carrying out organizational goals. In carrying out activities to move or provide motivation to subordinates, various ways can be done by a leader through actions that are always directed at the achievement of organizational goals. Various types and styles of leadership are often found in daily life. The purpose of this study was to determine whether there is an influence of situational leadership style on employee performance? The situational leadership style model was chosen because the situational leadership style approach is more focused on behavioral motives and the level of follower maturity (follower) to the task at the organization and is flexible so that it is considered an effective leadership style. This research was conducted at the Center for Apparatus Development of Human Resources (PPSDMA) Ministry of Energy and Mineral Resources in 2017. The data used are primary data with survey methods and secondary data from the results of related literature studies. Data processing using statistical methods of multiple linear regression analysis to determine the relationship of the influence of situational leadership style on employee performance. The results showed that simultaneously, situational leadership style variables would affect the performance variable. The results of the analysis of the research data revealed the influence of situational leadership variables on performance variables of $84.5 \%$, while the other $15.5 \%$ were influenced by other variables not included in this study. Situational leadership style, namely directing, selling, telling, participating, and delegating can be concluded to be appropriate to be applied in PPSDMA, but the most dominant is selling and participating.
\end{abstract}

Keywords: Situational Leadership Style, Employee Performance. 
Roni Rahmat Nugraha : Peranan Gaya Kepemimpinan Situasional Dalam Meningkatkan Kinerja Pegawai Pusat Pengembangan Sumber Daya Manusia Aparatur (PPSDMA)

\section{PENDAHULUAN}

\section{A. Latar Belakang}

Pusat Pengembangan Sumber Daya Manusia Aparatur, Badan Pengembangan SDM Kementerian Energi dan Sumber Daya Mineral (selanjutnya ditulis PPSDMA) merupakan lembaga atau instansi pemerintah yang dibentuk untuk berkiprah dalam meningkatkan kompetensi dan mendorong kinerja sumber daya manusia di Kementerian Energi dan Sumber Daya Mineral (selanjutnya ditulis KESDM) yang terdapat pada pasal 854 Peraturan Menteri ESDM Nomor 13 tahun 2016 tentang Organisasi dan Tata Kerja KESDM. PPSDM Aparatur sebagai satuan kerja di bawah BPSDM ESDM memiliki tugas untuk melaksanakan Pengembangan Sumber Daya Manusia Aparatur di bidang kepemimpinan, manajemen, dan administrasi untuk aparatur KESDM. PPSDMA telah menetapkan sasaran dan tujuan organisasi yang telah dituangkan dalam dokumen Renstra PPSDMA 2016-2019 dan Roadmap PPSDMA 2016-2025 yang tentunya membutuhkan sinergitas dan kinerja yang tinggi di antara semua pimpinan dan pegawai untuk mencapainya.

Peranan atasan atau pimpinan sangatlah besar bagi keberhasilan instansi atau organisasi dalam mencapai tujuan. Dari merekalah muncul gagasan-gagasan baru dan inovatif dalam pengembangan instansi atau organisasi. Namun demikian, bawahan juga memiliki peranan yang tidak kalah penting, karena bawahan inilah yang akan menjalankan dan melaksanakan gagasan pimpinan yang tertuang dalam setiap keputusan. Baik tidaknya bawahan melaksanakan tugas, tergantung dari pimpinan itu sendiri. Bagaimana seorang pemimpin memberikan dorongan dan motivasi untuk mempengaruhi para bawahnya melakukan berbagi tindakan sesuai dengan yang diharapkan. Kepemimpinan adalah kegiatan untuk memengaruhi perilaku orang lain, atau seni memengaruhi perilaku manusia baik perorangan maupun kelompok (Thoha, 2013).

Gaya kepemimpinan adalah cara yang digunakan oleh pemimpin untuk mempengaruhi bawahannya agar bekerja sesuai tujuan. Gaya kepemimpinan akan sangat berpengaruh terhadap baik buruknya organisasi yang dipimpinnya. Tidak ada gaya kepemimpinan yang buruk maupun gaya kepemimpinan yang baik. Semua tergantung kepada bagaimana keadaan dan bagaimana pula kondisi bawahan yang sedang dibimbing dan diarahkan. Seorang pemimpin harus mengetahui tingkat kemampuan dan kemauan pengikutnya sehingga kemudian dapat menerapkan gaya kepemimpinan yang sesuai dengan kondisi-kondisi tersebut.

Gaya kepemimpinan situasional merupakan gaya kepemimpinan yang dilakukan berdasarkan situasi yang ada. Penggunaan situasi untuk menentukan apa saja yang akan dilakukan menjadi sangat penting agar suatu organisasi bisa berjalan dengan baik. Perubahan situasi akan menyebabkan perubahan kebutuhan yang ada pada bawahan. Perbedaan tersebut menjadikan pemimpin harus memilih gaya kepemimpinan yang berbeda di situasi bawahan yang juga berbeda. Hal ini dilakukan agar setiap bawahan dipahami oleh pemimpin apa yang sedang dibutuhkannya dalam mengerjakan tugas yang diberikannya. Pengetahuan pemimpin terhadap apa yang dibutuhkan oleh bawahan hendaknya segera dipenuhi oleh pemimpin agar bawahan tersebut bisa bekerja secara lebih optimal.

Pengetahuan pemimpin terhadap kondisi bawahannya selanjutnya ditindak lanjuti dengan pemilihan gaya kepemimpinan yang paling tepat bagi para bawahan. Pemilihan gaya kepemimpinan yang sesuai dengan kondisi bawahan menjadikan bawahan akan bekerja seefektif dan seefisien mungkin. Hal ini tentunya akan sangat berpengaruh terhadap kinerja organisasi yang sedang dipimpinnya.

Pembahasan mengenai gaya kepemimpinan yang digunakan di berbagai organisasi telah banyak dilakukan penelitian. Pada kesempatan ini penulis menyampaikan kajian mengenai model gaya kepemimpinan situasional terhadap kinerja pegawai dikemukakan oleh Hersey \& Blanchard (1982) dimana lebih menekankan pada tingkat kematangan (maturity) bawahan yang terdiri dari: kemampuan (job maturity) dan kemauan (psychological maturity). Gaya kepemimpinanini sangat menarik untuk dikaji, contohnya seperti penelitian yang telah dilakukan oleh para peneliti berikut ini: penelitian pertama, oleh Ulya, Muhammad Ziauddin (2014), pada penelitian ini disimpulkan bahwa gaya kepemimpinan situasional yang berorientasi pada tugas dan berorientasi pada hubungan akan berpengaruh terhadap kinerja pegawai, baik secara simultan atau parsial. Kedua, oleh Kasmiruddin \& Ardelia (2015), bahwa gaya kepemimpinan yang meliputi empat komponen, yaitu telling, selling, participating, dan delegating, masing-masing memiliki indikator yang saling berkaitan dan 
Roni Rahmat Nugraha : Peranan Gaya Kepemimpinan Situasional Dalam Meningkatkan Kinerja Pegawai Pusat Pengembangan Sumber Daya Manusia Aparatur (PPSDMA)

berpengaruh positif terhadap kinerja pegawai. Ketiga, oleh Muh. Addin Syah (2017), hasil penelitian yang telah dilakukan didapati bahwa gaya kepemimpinan dan komunikasi organisasi berpengaruh positif dan signifikan baik secara parsial maupun simultan terhadap kinerja pegawai. Keempat, oleh Suryani yang menyatakan bahwa terdapat ada pengaruh variabel model kepemimpinan terhadap kinerja pegawai di organisasi yang diteliti, dan masih banyak lagi penelitian sejenis. Penulis dalam hal ini akan mencoba melihat hubungan gaya kepemimpinan situasional terhadap kinerja pegawai yang ada di PPSDMA.

\section{B. Rumusan Masalah}

Berdasarkan latar belakang masalah tersebut, seorang pemimpin akan memberikan pengaruh dan motivasi pada bawahnya untuk melakukan berbagai tindakan sesuai dengan yang diharapkan. Karena luasnya ruang lingkup gaya kepemimpinan ini, maka penulis membuat rumusan atau batasan masalah sebagai berikut:

1. Apakah perananan gaya kepemimpinan situasional para pimpinan dapat meningkatkan kinerja pegawai Pusat Pengembangan SDM Aparatur?

2. Gaya Kepemimpinan situasional yang manakah dapat diterapkan pimpinan yang berpengaruh pada Pusat Pengembangan SDM Aparatur?

\section{Tujuan dan Manfaaat Penelitian}

Penelitian ini bertujuan untuk mengidentifikasi peranan gaya kepemimpinan situasional dalam meningkatkan kinerja pegawai di lingkungan Pusat Pengembangan Sumber Daya Manusia Aparatur.

Hasil penelitian ini diharapkan dapat mengungkap pengaruh gaya kepemimpinan dari para pimpinan terhadap perilaku kinerja pegawai di bawahnya, sehingga dengan memilih model atau gaya kepemimpinan yang tepat diharapkan dapat meningkatkan kinerja individu pegawai sehingga pada akhirnya akan meningkatkan kinerja organisasi.

\section{TINJAUAN PUSTAKA}

\section{A. Tinjauan Pustaka}

\section{Pengertian Kepemimpinan}

Menurut Hasibuan (2007:170), kepemimpinan adalah "Proses mempengaruhi orang lain untuk memahami dan setuju tentang apa yang akan dikerjakan serta bagaimana tugas itu dapat dilakukan secara efektif dan proses memfasilitasi usaha individu dan kelompok untuk mencapai tujuan bersama".

Sedangkan Tzu dan Cleary (2002:5), berpendapat berbeda bahwa kepemimpinan adalah "Sebuah persoalan kecerdasan, kelayakan untuk dipercaya, kelembutan, keberanian, dan ketegasan".

Menurut Anoraga yang dikutip oleh Sutisna (2011:214), berpendapat hampir sama dengan Hasibuan, bahwa kepemimpinan adalah "Kemampuan untuk mempengaruhi pihak lain, melalui komunikasi, baik langsung maupun tidak langsung dengan maksud untuk menggerakan orang-orang agar dengan penuh pengertian, kesadaran, dan senang hati bersedia mengikuti kehendak pimpinan itu".

Dengan demikian dapat dikatakan bahwa arti kepemimpinan adalah kemampuan mempengaruhi dan menggerakkan pihak lain dengan sadar mengikuti pimpinan yang memiliki sosok layak dipercaya, cerdas, berani, lembut tapi tegas untuk mencapai tujuan bersama.

\section{Gaya Kepemimpinan}

Dalam melakukan kegiatan menggerakkan atau memberikan motivasi kepada bawahannya, berbagai cara dapat dilakukan oleh seorang pemimpin, yakni dengan melakukan tindakantindakan yang selalu terarah pada pencapaian tujuan organisasi. Berbagai tipe dan gaya kepemimpinan tersebut banyak dijumpai dalam kehidupan sehari-hari

Berikut ini akan diuraikan beberapa definisi dari gaya kepemimpinan dari para ahli tersebut, diantaranya:

1) Menurut House Robbins yang dikutip oleh Donni dan Suwatno (2011:158), gaya kepemimpinan dapat dibagi menjadi empat yaitu: a) Kepemimpinan direktif, kepemimpinan ini membuat bawahan tahu apa yang diharapkan pimpinan dari mereka, menjadwalkan kerja untuk dilakukan, dan memberi bimbingan khusus mengenai bagaimana menyelesaikan tugas. b) Kepemimpinan yang mendukung, Kepemimpinan ini bersifatramah dan menunjukkan kepedulian akan kebutuhan bawahan. c. Kepemimpinan partisipatif, Kepemimpinan ini berkonsultasi dengan bawahan dan menggunakan saran mereka sebelum mengambil keputusan. d) Kepemimpinan Berorientasi pada Prestasi, 
Roni Rahmat Nugraha : Peranan Gaya Kepemimpinan Situasional Dalam Meningkatkan Kinerja Pegawai Pusat Pengembangan Sumber Daya Manusia Aparatur (PPSDMA)

Kepemimpinan ini menetapkan tujuan yang menantang dan mengharapkan bawahan untuk berprestasi pada tingkat tertinggi mereka.

2) Menurut Hasibuan (2011), terdapat tiga gaya kepemimpinan, yaitu: a) Kepemimpinan otoriter, adalah jika kekuasaan atau wewenang sebagian besar mutlak tetap berada pada pimpinan atau kalau pimpinan itu menganut sistem sentralisasi wewenang. Pengambilan keputusan dari kebijaksanaan hanya ditetapkan sendiri oleh pimpinan, bawahan tidak diikutsertakan untuk memberikan saran, ide dan pertimbangan dalam proses pengambilan keputusan. b) Kepemimpinan partisipatif, adalah apabila dalam kepemimpinannya dilakukan dengan cara persuasif, menciptakan kerjasama yang serasi, menumbuhkan loyalitas dan partisipasi para bawahan. Pimpinan memotivasi bawahan agar merasa ikut memiliki instansi atau organisasi.

c) Kepemimpinan delegatif, adalah seorang pemimpin mendelegasikan wewenang kepada bawahan dengan agak lengkap, dengan demikian bawahan dapat mengambil keputusan dan kebijaksanaan dengan bebas atau leluasa dalam melaksanakan pekerjaannya. Pemimpin tidak peduli cara bawahan mengambil keputusan dan mengerjakan pekerjaannya, sepenuhnya diserahkan kepada bawahan.

\section{Gaya Kepemimpinan Situasional}

Gaya kepemimpinan situasional yang dikemukakan Hersey \& Blanchard (1996) adalah gaya kepemimpinan dengan pendekatan lebih fokus terhadap pengikut atau pegawai pada organisasi. Pemimpin harus mampu memperhatikan kesiapan dan kematangan pegawainya untuk menjalankan pekerjaan yang telah ditentukan. Gaya kepemimpinan situasional didasarkan pada hubungan seperti, jumlah petunjuk yang diberikan pemimpin, jumlah dukungan emosional, dan tingkat kematangan pegawai. Gaya kepemimpinan situasional memiliki empat dimensi, antara lain telling, selling, participant, dan delegating (Putra \& Yuniawan, 2015), diuraikan sebagai berikut :

a) Gaya kepemimpinan instruksi atau telling (G1); adalah seorang pemimpin menunjukkan perilaku yang banyak memberikan pengarahan namun sedikit dukungan. Pemimpin ini memberikan instruksi yang spesifik tentang peranan dan tujuan bagi pengikutnya, dan secara ketat mengawasi pelaksanaan tugas mereka.

b) Gaya kepemimpinan konsultasi atau selling (G2); adalah pemimpin menunjukkan perilaku yang banyak mengarahkan dan banyak memberikan dukungan. Pemimpin dalam gaya seperti ini mau menjelaskan keputusan dan kebijaksanaan yang ia ambil dan mau menerima pendapat dari pengikutnya. Tetapi pemimpin dalam gaya ini masih tetap harus memberikan pengawasan dan pengarahan dalam penyelesaian tugas-tugas pengikutnya.

c) Gaya kepemimpinan partisipasi atau participating (G3); adalah perilaku pemimpin yang menekankan pada banyak memberi dukungan namun sedikit dalam pengarahan. Dalam gaya seperti ini pemimpin menyusun keputusan bersama-sama dengan para pengikutnya, dan mendukung usaha-usaha mereka dalam menyelesaikan tugas.

d) Gaya kepemimpinan delegasi atau delegating (G4); adalah pemimpin memberikan sedikit dukungan dan sedikit pengarahan. Pemimpin dengan gaya seperti ini mendelegasikan keputusan-keputusan dan tanggung jawab pelaksanaan tugas kepada pengikutnya.

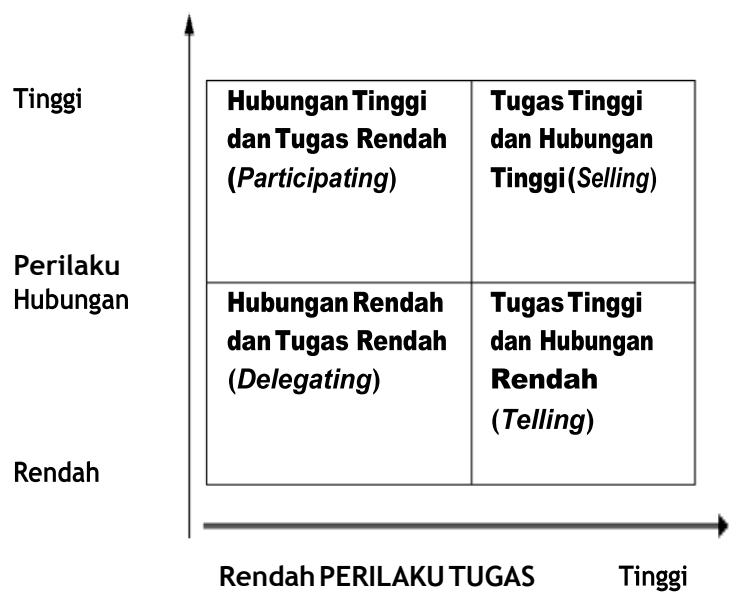

Sumber: Hersey \& Blanchard (1996), diolah kembali

Gambar 1. Gaya Kepemimpinan Situasional

Berdasarkan Gambar 1, dapat dijelaskan titik potong perilaku tugas dan perilaku hubungan. Apabila pada perilaku tugas rendah dan perilaku hubungan rendah, seorang pemimpin haruslah memperhatikan dan mendorong pegawainya untuk mencapai tingkat kematangan yang tinggi dan dapat menggunakan gaya kepemimpinan yang mengarahkan pegawainya untuk hasil yang maksimal. 
Roni Rahmat Nugraha : Peranan Gaya Kepemimpinan Situasional Dalam Meningkatkan Kinerja Pegawai Pusat Pengembangan Sumber Daya Manusia Aparatur (PPSDMA)

\section{Definisi Kinerja}

Pengertian kinerja secara umum adalah performa atau unjuk kerja. Berikut ini beberapa definisi dari para ahli.

Hasibuan (2007:195) menyatakan: "Kinerja atau unjuk kerja merupakan hasil kerja yang dihasilkan oleh pegawai atau perilaku yang nyata yang ditampilkan sesai dengan perannya dalam organisasi”.

Melengkapi pendapat Hasibuan, menurut Mangkunegara (2001:67) bahwa kinerja (prestasi kerja): "kinerja adalah hasil kerja secara kualitas dan kuantitas yang dicapai seorang pegawai dalam melaksanakan tugasnya sesuai dengan tanggung jawab yang diberikan kepadanya".

Definisi yang sama dari Hasibuan, dikemukakan Rivai (2004:309) bahwa: "kinerja adalah merupakan perilaku yang nyata yang ditampilkan setiap orang sebagai prestasi kerja yang dihasilkan oleh pegawai sesuai dengan perannya dalam instansi atau organisasi".

Sedangkan menurut Whitmore (2002:104), bahwa "kinerja" dengan asal kata "kerja" berarti aktivitas yang dilakukan oleh seseorang atau organisasi dalam menjalankan tugas yang menjadi pekerjaannya. Kinerja merupakan suatu perbuatan, suatu prestasi, atau penampilan umum dari keterampilan.

Sehingga dapat dikatakan secara umum bahwa, kinerja dapat dipahami sebagai aktivitas dan hasil kerja baik secara kualitas maupun kuantitas yang dapat dicapai oleh seseorang atau sekelompok orang dalam suatu organisasi sesuai dengan wewenang dan tanggung jawab masingmasing, guna mencapai tujuan organisasi yang bersangkutan.

\section{Indikator dan Faktor Kinerja}

Terdapat beberapa faktor yang menjadi indikator maupun kriteria penilaian kinerja pegawai, diantaranya sebagai berikut. Menurut Heijrachman dan Husnan (1990:126) dalam Pratama (2015), indikator penilaian kinerja diantaranya :

a) Kualitas kerja; Indikator ini terdiri dari ketepatan, ketelitian, kerapian dalam melaksanakan tugas dan pekerjaan, pemeliharaan alat-alat kerja, dan kecakapan dalam melaksanakan tugas.

b) Kuantitas kerja; Indikator ini meliputi output, bukan hanya output rutin, tetapi juga seberapa cepat pekerjaan bisa diselesaikan.

c) Keandalan; Merupakan pengukuran dari segi kemampuan atau keandalan pegawai dalam melaksanakan tugas, meliputi instruktur, inisiatif, kehati-hatian, seperti dalam hal keandalan pelaksanaan prosedur, peraturan kerja, disiplin, dan lain-lain.

d) Sikap; Merupakan perilaku pegawai terhadap perusahaan, terhadap rekan sekerja, pekerjaan, serta kerjasama dengan pegawai lain.

Selain itu menurut Tsui et. al dalam Mas'ud (2004:213), menyatakan "indikator kinerja" adalah sebagai berikut:

a) Kuantitas kerja pegawai; "Kuantitas merupakan jumlah yang dihasilkan dan dinyatakan dalam istilah seperti jumlah unit atau jumlah siklus aktivitas yang diselesaikan". Kuantitas yang diukur dari persepsi pegawai terhadap jumlah aktivitas yang ditugaskan beserta hasilnya.

b) Kualitas kerja pegawai; "Kualitas adalah ketaatan dalam prosedur, disiplin, dan dedikasi". Tingkat dimana hasil aktivitas yang dikehendaki mendekati sempurna dalam arti menyesuaikan beberapa cara ideal dari penampilan aktivitas, maupun memenuhi tujuan-tujuan yang diharapkan dari suatu aktivitas. Kualitas kerja diukur dari persepsi pegawai terhadap kualitas pekerjaan yang dihasilkan serta kesempurnaan tugas terhadap keterampilan dan kemampuan pegawai.

c) Efisiensi pegawai; "Efisiensi pe gawai adalah kemampuan pegawai untuk memanfaatkan tiap sumber daya dengan baik secara maksimal".

d) Usaha pegawai; "Usaha pegawai adalah kesadaran dalam diri pegawai untuk bekerja dengan penuh dedikasi dan berusaha lebih baik lagi".

e) Standar profesional pegawai; "Standar profesional pegawai merupakan ketaatan pegawai yang bersangkutan dalam menghormati perjanjian kerja dengan perusahaaan dimana dia bekerja".

f) Kemampuan pegawai; "Kemampuan yang dimiliki pegawai sesuai terhadap pekerjaan inti dan kemampuan pegawai dalam menggunakan akal sehat".

Berdasarkan pendapat Simamora (Mangkunegara, 2009:14) yang mengatakan bahwa kinerja (performance) dipengaruhi oleh tiga faktor atau dimensi, yaitu faktor/dimensi individual (atribut individu), faktor/dimensi psikologis (upaya kerja atau work effort), dan faktor/dimensi organisasi (dukungan organisasi. 
Roni Rahmat Nugraha : Peranan Gaya Kepemimpinan Situasional Dalam Meningkatkan Kinerja Pegawai Pusat Pengembangan Sumber Daya Manusia Aparatur (PPSDMA)

Kinerja kerja individu menurut Wood et.al (2001), bahwa ditentukan atau dipengaruhi oleh atribut individu (individual attributes), usaha dalam bekerja (work effort), dan dukungan organisasional. Menurut Robbins (2015), karakteristik individu mencakup umur, jenis kelamin, tingkat pendidikan, status perkawinan, dan masa kerja dalam organisasi. Pada penelitian ini penulis menggunakan indikator kinerja masa kerja dan tingkat pendidikan saja.

\section{Hubungan antara Gaya Kepemimpinan dan Kinerja Pegawai}

Gaya kepemimpinan merupakan suatu cara yang dimiliki oleh seseorang dalam mempengaruhi sekelompok orang atau bawahan untuk bekerja sama dan berdaya upaya dengan penuh semangat dan keyakinan untuk mencapai tujuan yang telah ditetapkan. Keberhasilan suatu organisasi baik sebagai keseluruhan maupun berbagai kelompok dalam suatu organisasi tertentu, sangat tergantung pada efektivitas kepemimpinan yang terdapat dalam organisasi yang bersangkutan. Dapat dikatakan bahwa mutu kepemimpinan yang terdapat dalam suatu organisasi memainkan peranan yang sangat dominan dalam keberhasilan organisasi tersebut dalam menyelenggarakan berbagai kegiatannya terutama terlihat dalam kinerja para pegawainya (Siagian, 1999).

Thoha (2010, h.42), mengungkapkan bahwa dengan mempergunakan kepemimpinan maka pemimpin akan mempengaruhi persepsi bawahan dan memotivasinya, dengan cara mengarahkan karyawan pada kejelasan tugas, pencapaian tujuan, kepuasan kerja, dan pelaksanaan kerja yang efektif. Hal ini dipertegas oleh Robbins (2007, h.432) yang mengungkapkan bahwa kepemimpinan sebagai kemampuan untuk mempengaruhi suatu kelompok menuju pencapaian sasaran. Kemampuan karyawan untuk mencapai sasaran dan tujuan organisasi tersebut merupakan pencerminan dari kinerja karyawan.

Cunningham dan Cordeiro (2003:140-141), bahwa gaya kepemimpinan mempengaruhi perilaku bawahannya, terutama perilaku bawahan yang mendukung penggunaan gaya yang disukai (leadership style may in fact, influence the behavior of subordinates in such a away that the subordinates behavior actually supports the use of the leader's preferred style, becoming a selffulfilling prophecy). Hal ini menunjukkan bahwa gaya kepemimpinan akan berpengaruh terhadap kepercayaan pegawai, terutama penggunaan gaya kepemimpinan yang disukai pegawainya.

Sehingga dapat disimpulkan jika gaya kepemimpinan memiliki peran yang besar dalam meningkatkan kinerja pegawai.

\section{B. Kerangka Pikir}

Berdasarkan perumusan masalah tersebut dan dasar-dasar teori tentang pengaruh gaya kepemimpinan terhadap kinerja pegawai, maka kerangka pikir untuk melihat tingkat pengaruh variabel gaya kepemimpinan situasional menurut Hersey \& Blanchard terhadap variabel kinerja menurut indikator Tsui et.al dijelaskan seperti pada gambar 2 sebagai berikut :

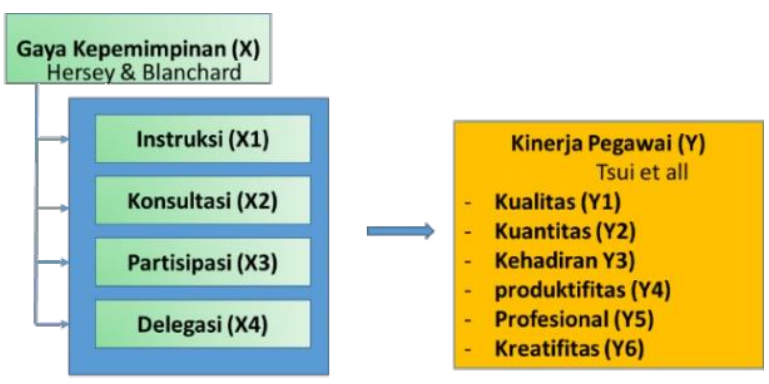

Sumber: hasil olah penulis, 2017

Gambar 2.

Kerangka Pikir Pengaruh Gaya Kepemimpinan Situasional terhadap Kinerja Pegawai

\section{METODOLOGI PENELITIAN}

\section{A. Sumber dan Metode Pengumpulan Data}

Penelitian ini menggunakan sumber data, baik primer dan sekunder. Metode primer dilakukan dengan cara pengamatan langsung dan penyebaran kuesioner melalui angket. Penentuan jumlah sampel dari populasi pegawai sejumlah 50 dapat dihitung dengan menggunakan rumus Slovin (dalam Sugiyono 2007 : 87) maka jumlah sampelnya adalah kurang lebih 30 orang.

Penentuan jumlah sampel dapat dihitung dengan menggunakan rumus Slovin (dalam Sugiyono 2007 : 87) sebagai berikut:

Dimana:

$$
\begin{aligned}
\mathrm{n}= & \text { Jumlah Sampel } \\
\mathrm{N}= & \text { Jumlah Populasi } \\
\mathrm{d}= & \text { Presisi } / \text { ketelitian }(95 \%) \text { atau tingkat } \\
& \text { kesalahan } 10 \%(0,1)
\end{aligned}
$$

Sehingga dapat dihitung sebagai berikut:

$$
\begin{aligned}
& \mathrm{n}=52 \\
& \quad 52(0,1)^{2}+1
\end{aligned}
$$


Roni Rahmat Nugraha : Peranan Gaya Kepemimpinan Situasional Dalam Meningkatkan Kinerja Pegawai Pusat Pengembangan Sumber Daya Manusia Aparatur (PPSDMA)

$$
\mathrm{n}=\mathrm{52}
$$

Berdasarkan rumus ini Sehingga dengan mengomakan rumus ini maka jumlah sampelnya adalah 34 orang.

Sedangkan pengumpulan data sekunder dilakukan dengan cara membaca dan mengumpulkan data-data, diantaranya target kinerja dari instansi PPSDMA, dokumen Rencana Strategis PPSDMA tahun 2016-2019, dan Roadmap PPSDM Aparatur 2016-2025 serta data komposisi pegawai dari Bagian Tata Usaha PPSDMA.

\section{B. Variabel Penelitian dan Definisi Operasional}

\section{Variabel Penelitian}

a. Independen Variabel / Variabel Bebas Dalam penelitian ini yang menjadi variabel bebas adalah Gaya Kepemimpinan $=\mathrm{X}$.

b. Dependen Variabel / Variabel Terikat Yang menjadi variabel terikat adalah Kinerja $=\mathrm{Y}$

\section{Definisi Operasional}

Untuk mempermudah mengukur variabel di dalam penelitian ini berdasarkan gaya kepemimpinan situasional yang dikemukakan Hersey \& Blanchard (1996) dan Kinerja menurut Tsui et.al (1997), maka ditentukan definisi operasional sebagai berikut.

a. Gaya kepemimpinan $(\mathrm{X})$

Dimensi gaya kepemimpinan akan diukur menurut Hersey dan Blanchard (1996) berdasarkan masing-masing indikatornya yang akan diuraikan dalam pertanyaan pada kuesioner sebagai berikut:

1) Gaya Kepemimpinan Directive atau Instruktif

2) Gaya Kepemimpinan Selling atau Konsultatif

3) Gaya Kepemimpinan Suppporting atau Partisipatif

4) Gaya Kepemimpinan Delegating

b. Kinerja Pegawai (Y)

Kinerja pegawai adalah: suatu prestasi/ hasil kerja yang dicapai seorang pegawai dalam melaksanakan tugasnya. Variabel dan indikator- indikator yang menjadi bagian dari konsep ini adalah indikator penilaian kinerja pegawai menurut Tsui et al (1997) yang akan diuraikan dalam pertanyaan pada kuesioner.

\section{Deskripsi Variabel Penelitian untuk bahan Kuesioner atau Angket}

Dalam penelitian ini terdapat 2 (dua) variabel yang diteliti, terdiri dari 1 (satu) variabel terikat dan 1 (satu) variabel bebas. Variabel bebas, yaitu gaya kepemimpinan, terdiri dari 4 (empat) dimensi, yaitu Directing, Selling, Supporting, dan Delegating serta kinerja sebagai variabel terikat. Melalui kuesioner yang telah disebarkan, diperoleh data mengenai variabel dan dimensi tersebut sebagai berikut :

a. Gaya Kepemimpinan Directing $\left(\mathrm{X}_{1}\right)$

Pada dimensi directing ini pada kuesioner diwakili oleh 9 indikator yang dapat menggambarkan respon terhadap dimensi ini. Kesembilan indikator tersebut antara lain:

1) Instruksi yang jelas dan detil

2) Memberitahukan yang jelas

3) Melakukan pengawasan yang ketat

4) Komunikasi satu arah

5) Membuat keputusan berdasarkan informasi dirinya

6) Merencanakan langkah yang jelas dalam pengawasan

7) Memantau tindakan bawahan

8) Menunjukan cara kerja yang baku dalam pekerjaan

9) Pimpinan memberikan instruksi atau arahan

b. Gaya Kepemimpinan Selling $\left(\mathrm{X}_{2}\right)$

Pada dimensi selling ini pada kuesioner diwakili oleh 4 indikator yang dapat menggambarkan respon terhadap dimensi ini. Keempat indikator tersebut antara lain:
1) berdiskusi
2) pengawasan wajar
3) mendengarkan
4) komunikasi dua arah,

c. Gaya Kepemimpinan Supporting $\left(\mathrm{X}_{3}\right)$

Pada dimensi supporting ini pada kuesioner, diwakili oleh 3 indikator yang dapat menggambarkan respon terhadap dimensi ini. Ketiga indikator tersebut antara lain:
1) Mengikutsertakan
2) Memberi semangat
3) Kerja sama

d. Gaya Kepemimpinan Delegating $\left(\mathrm{X}_{3}\right)$

Pada dimensi Delegating ini didalam kuesioner diwakili oleh 4 indikator yang dapat menggambarkan respon terhadap dimensi ini. Keempat indikator tersebut antara lain:

1) Mendelegasikan 
Roni Rahmat Nugraha : Peranan Gaya Kepemimpinan Situasional Dalam Meningkatkan Kinerja Pegawai Pusat Pengembangan Sumber Daya Manusia Aparatur (PPSDMA)

2) Pengamatan

3) Mengawasi

4) Penyelesaian

e. $\operatorname{Kinerja~(Y)}$

Pada variabel kinerja ini didalam kuesioner diwakili oleh 7 indikator yang dapat menggambarkan respon terhadap variabel ini. Ketujuh indikator tersebut antara lain:
1) Kualitas kerja
2) Kuantitas kerja
3) profesional
4) Kehadiran ditempat kerja
5) Sikap koperatif
6) Tanggung jawab
7) Kepercayaan dan kerja tim

\section{Teknik Pengumpulan Data dan Analisis Data}

\section{Pembuatan Angket atau Kuesioner}

Kuesioner merupakan teknik pengumpulan data yang dilakukan dengan cara memberi seperangkat pertanyaan tertulis kepada responden untuk dijawabnya. Dalam hal ini responden hanya menjawab dengan cara memberi tanda tertentu pada alternatif jawaban yang disediakan

Data hasil survai yang diperoleh dari kuesioner akan diolah dengan pendekatan kuantitatif menggunakan skala Likert sebagai berikut: a) Sangat Tidak Setuju $=1$, b) Tidak Setuju $=2$, c) Netral/Cukup Setuju $=3$, d) Setuju $=4$, e) Sangat Setuju $=5$

\section{Analisis data}

Untuk melihat pengaruh keempat dimensi gaya kepemimpinan $\left(\mathrm{X}_{1}, \mathrm{X}_{2}, \mathrm{X}_{3}, \mathrm{X}_{4}\right)$ ini terhadap kinerja pegawai (Y) ini akan dianalisis dengan menggunakan Analisis Regresi Linier Berganda dengan rumus sebagai berikut: (Ghozali, 2013).

$$
Y=b_{0}+b_{1} X 1+b_{2} X 2+b_{3} X 3+b_{4} X 4+e_{i}
$$

$$
\begin{aligned}
\text { Keterangan: } & \\
\mathrm{Y}(\mathrm{y} 1 \ldots \mathrm{y} 8) & \text { Kinerja Pegawai sebagai } \\
& \text { Variabel Dependen } \\
= & \text { Konstanta } \\
= & \text { Koefisien garis regresi } \\
\mathrm{b}_{0} & \text { Gaya Kepemimpinan } \\
\mathrm{b}_{1}-\mathrm{b}_{4} & \text { Directing sebagai dimensi } \\
\mathrm{X}_{1}(\mathrm{x} 1.1 . . \mathrm{x} 1 \mathrm{n} .) & \text { variabel indepen } \\
\mathrm{X}_{2}(\mathrm{x} 2.1 . . \mathrm{x} 2 \mathrm{n} .)= & \text { Gaya Kepemimpinan Selling } \\
& \text { sebagai dimensi variabel } \\
& \text { indepen }
\end{aligned}
$$

$$
\begin{aligned}
\mathrm{X}_{3}(\mathrm{x} 3.1 . . \mathrm{x} 3 \mathrm{n} .)= & \begin{array}{l}
\text { Gaya } \\
\text { Supporting sebagai dimensi }
\end{array} \\
& \text { variabel indepen } \\
\mathrm{X}_{4}(\mathrm{x} 4.1 . . \mathrm{x} 4 \mathrm{n} .)= & \begin{array}{l}
\text { Gaya kememimpinan } \\
\text { Delegating sebagai dimensi }
\end{array} \\
& \text { variabel indepen } \\
= & \text { Standar error }
\end{aligned}
$$

\section{Pengujian Hipotesis}

a. Uji Signifikansi Simultan (Uji Statistik F)

Dalam penelitian ini, uji $\mathrm{F}$ digunakan untuk mengetahui tingkat signifikansi pengaruh variabel-variabel independen secara bersamasama (simultan) terhadap variabel dependen (Ghozali, 2013). Dalam penelitian ini, hipotesis yang digunakan adalah,

Ho : Variabel bebas yaitu gaya kepemimpinan tidak mempunyai pengaruh yang signifikan terhadap variabel terikatnya yaitu kinerja pegawai.

Ha : Variabel bebas yaitu gaya kepemimpinan mempunyai pengaruh yang signifikan terhadap variabel terikatnya yaitu kinerja pegawai.

b. Uji Signifikasi Pengaruh Parsial (Uji - t ) Uji t digunakan untuk menguji signifikansi hubungan antara variabel $\mathrm{X}$ dan $\mathrm{Y}$, apakah variabel $X$ (gaya kepemimpinan) benar-benar berpengaruh terhadap variabel Y (kinerja pegawai) secara terpisah atau parsial (Ghozali, 2013). Hipotesis yang digunakan dalam pengujian ini adalah :

- Ho: Variabel bebas (gaya kepemimpinan) tidak mempunyai pengaruh yang signifikan terhadap variabel terikat (kinerja pegawai).

- Ha: Variabel bebas (gaya kepemimpinan) mempunyai pengaruh yang signifikan terhadap variabel terikat (kinerja pegawai).

\section{c. Analisis Koefisien Determinasi $\left(\mathbf{R}^{2}\right)$}

Koefisien determinasi $\left(\mathrm{R}^{2}\right)$ pada intinya mengukur seberapa jauh kemampuan model dalam menerangkan variasi variabel terikat $\mathrm{Y}$ $=\mathrm{a}+\mathrm{b} 1 \mathrm{X} 1+\mathrm{e}$ (Ghozali, 2013). Nilai Koefisien determinasi adalah antara nol dansatu. Nilai $R^{2}$ yang kecil berarti kemampuan variabel bebas (model kepemimpinan) dalam menjelaskan variasi variabel terikat (kinerja pegawai) amat terbatas. Begitu pula sebaliknya, nilai yang mendekati satu berarti variabel bebas memberikan hampir 
Roni Rahmat Nugraha : Peranan Gaya Kepemimpinan Situasional Dalam Meningkatkan Kinerja Pegawai Pusat Pengembangan Sumber Daya Manusia Aparatur (PPSDMA)

semua informasi yang dibutuhkan untuk memprediksi variasi variabel terikat.

\section{HASIL ANALISIS DAN PEMBAHASAN}

\section{A. Hasil Analisis}

\section{Hasil Uji validitas dan Realibilitas Instrumen Kuesioner}

Berdasarkan uji validitas dan uji reliabilitas pada seluruh variabel, terdapat 44 pertanyaan yang telah diberikan kepada 50 populasi pegawai dan 30 responden yang menanggapi. Pada uji validitas semua nilai yang diperoleh $r$ hitung lebih besar daripada nilai $r$ tabel, dengan hal ini, semua pertanyaan pada kuesioner dikatakan valid. Sedangkan uji reliabilitas, nilai yang dihasilkan melalui nilai Cronbach's Alpha. Pada variabel gaya kepemimpinan situasional yang terdapat 35 pertanyaan, dan kinerja pegawai ada 9 pertanyaan. Semua nilai yang dihasilkan lebih besar daripada 0,60 , maka pada uji reliabilitas ini dapat dikatakan reliabel.

\section{Hasil Uji Hipotesis Pengaruh Variabel} Gaya Kepemimpinan Situasional dan Kinerja

Pembuktian hipotesis secara simultan menggunakan uji F. Hasil uji berpengaruh apabila $\mathrm{F}$ hitung $>\mathrm{F}$ tabel. Dari hasil perhitungan menunjukan bahwa $\mathrm{F}$ hitung adalah sebesar 66.746 dan $\mathrm{F}$ tabel dengan level signifikan 0,05\% $=2,56$. Maka diperoleh $\mathrm{F}$ hitung lebih besar dari F tabel (66.746 > 2.56).

Dengan demikian hipotesis mengatakan dimensi-dimensi variabel Gaya Kepemimpinan Situasional terdiri dari Directing $\left(\mathrm{X}_{1}\right)$, Selling $\left(\mathrm{X}_{2}\right)$, Supporting $\left(\mathrm{X}_{3}\right)$, dan Delegating $\left(\mathrm{X}_{4}\right)$ merupakan faktor yang mempengaruhi terhadap kinerja pegawai pada Pusat Pengembangan SDM Aparatur KESDM diterima.

Dari hasil perhitungan tersebut maka apakah variabel Directing $\left(\mathrm{X}_{1}\right)$, Selling $\left(\mathrm{X}_{2}\right)$, Supporting $\left(\mathrm{X}_{3}\right)$, dan Delegating $\left(\mathrm{X}_{4}\right)$ secara bersama-sama berpengaruh kepada kinerja pegawai Pusat Pengembangan SDM Aparatur KESDM.

\section{Koefisien Determinasi R2}

Tabel 1. Koefisien determinasi R2 Model Summary b

\begin{tabular}{|c|c|c|c|c|c|}
\hline Model & $\mathrm{R}$ & $\mathrm{R}$ Square & $\begin{array}{c}\text { Adjusted R } \\
\text { Square }\end{array}$ & $\begin{array}{c}\text { Std. Error of } \\
\text { the Estimate }\end{array}$ & $\begin{array}{l}\text { Durbin- } \\
\text { Watson }\end{array}$ \\
\hline 1 & $.919 \mathrm{a}$ & .845 & .832 & .833 & 1.220 \\
\hline
\end{tabular}

a. Predictors: (Constant), delegating, selling, directing, supporting

b. Dependent Variable: kinerja

Berdasarkan hasil analisis regresi linear berganda dari pengolahan data seperti terlihat dari tabel 1, maka dihasilkan persamaan regresi linier berganda sebagai berikut:

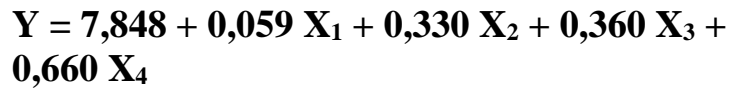

Berdasarkan hasil analisis regresi linear berganda tersebut, diperoleh koefisien untuk variabel Directing $\left(\mathrm{X}_{1}\right)$ sebesar 0,059 variabel, Selling $\left(\mathrm{X}_{2}\right)$ sebesar 0,330 , variabel supporting $\left(\mathrm{X}_{3}\right)$ sebesar 0,360, variabel Delegating $\left(\mathrm{X}_{4}\right)$ sebesar 0,667, dan konstanta sebesar 7,848.

\section{Pembahasan}

Pembuktian hipotesis secara parsial dilakukan untuk melihat pengaruh masing-masing variabel bebas secara sendiri-sendiri (4 dimensi dari variabel gaya kepemimpinan situasional) terhadap variabel terikatnya (kinerja pegawai), sehingga nantinya dapat diketahui variabel bebas mana yang paling dominan yang mempengaruhi variabel terikat, yakni kinerja Pegawai pada Pusat Pengembangan SDM Aparatur KESDM dari keempat dimensi variabel bebas gaya kepemimpinan situasional yang diteliti dalam penelitian ini.

Berdasarkan pengujian pada dimensi variabel Directing $\left(\mathrm{X}_{1}\right)$ dengan mengunakan bantuan SPSS diperoleh t hitung sebesar sebesar 0,362 . Maka bila dibandingkan pada $t$ tabel pada signifikan a $=5 \%$, yakni sebesar 2.00 dapat dilihat bahwa t hitung lebih kecil dari pada $t$ tabel $(0.362$ $<2.00$ ) dengan demikian dapat disimpulkan dimensi variabel $\mathrm{X}_{1}$ atau Directing tidak berpengaruh positif dan signifikan terhadap kinerja pegawai Pusat Pengembangan SDM Aparatur KESDM.

Berdasarkan pengujian pada dimensi variabel Selling $\left(\mathrm{X}_{2}\right)$ diperoleh t hitung sebesar sebesar 3.797. Maka bila dibandingkan pada $\mathrm{t}$ tabel pada signifikan a $=5 \%$, yakni sebesar 2.00 dapat dilihat bahwa $t$ hitung lebih besar dari pada t tabel $(3.797>2.00)$. Dengan demikian dapat disimpulkan dimensi variabel $\mathrm{X}_{2}$ atau Selling secara parsial memiliki hubungan yang kuat dalam mempengaruhi kinerja pegawai Pusat Pengembangan SDM Aparatur KESDM. 
Roni Rahmat Nugraha : Peranan Gaya Kepemimpinan Situasional Dalam Meningkatkan Kinerja Pegawai Pusat Pengembangan Sumber Daya Manusia Aparatur (PPSDMA)

Pengujian pada dimensi variabel Supporting $\left(\mathrm{X}_{3}\right)$ diperoleh $\mathrm{t}$ hitung sebesar sebesar 2.361. Maka apabila dibandingkan pada $\mathrm{t}$ tabel pada signifikan a $=5 \%$, yakni sebesar 2.00, dapat dilihat bahwa t hitung lebih besar dari pada t tabel $(2.361>2.00)$, dengan demikian dapat disimpulkan dimensi variabel $\mathrm{X}_{3}$ atau supporting berpengaruh positif dan signifikan terhadap kinerja pegawai Pusat Pengembangan SDM Aparatur KESDM.

Maka berdasarkan pengujian pada dimensi variabel Delegating $\left(\mathrm{X}_{4}\right)$ diperoleh $\mathrm{t}$ hitung sebesar 6.738. Maka bila dibandingkan pada $\mathrm{t}$ tabel pada signifikan a $=5 \%$, yakni sebesar 2.00, dapat dilihat bahwa thitung lebih besar dari pada t tabel $(6.738>2.00)$, dengan demikian dapat disimpulkan dimensi variabel $\mathrm{X}_{4}$ atau Delegating mempengaruhi positif dan signifikan terhadap kinerja pegawai Pusat Pengembangan SDM Aparatur KESDM.

Hasil analisis dengan metode statistik regresi linear akan diinterpretasikan sebagai berikut:

a Nilai 7,848 artinya pada saat faktor Directing $\left(\mathrm{X}_{1}\right)$, Selling $\left(\mathrm{X}_{1}\right)$, Supporting $\left(\mathrm{X}_{4}\right)$, dan Delegating $\left(\mathrm{X}_{4}\right)$, dianggap tidak ada (sama dengan nol) maka kinerja pada Pusat Pengembangan SDM Aparatur KESDM agak meningkat sebesar 7,848

6 Koefisien regresi Directing $\left(\mathrm{X}_{1}\right) \quad(\mathbf{0 , 0 5 9})$ menunjukan bahwa setiap terjadi kenaikan pada factor Directing sebesar 1 satuan, maka kinerja akan berubah meningkat sebesar $\mathbf{0 , 0 5 9}$ satuan

c Koefisien regresi Selling $\left(\mathrm{X}_{2}\right) \quad(\mathbf{0 , 3 3 0})$ menunjukan bahwa setiap terjadi kenaikan pada factor Selling sebesar 1 satuan, maka kinerja akan berubah meningkat sebesar $\mathbf{0 , 3 3 0}$ satuan

$d$ Koefisien regresi Supporting $\left(\mathrm{X}_{3}\right) \quad(\mathbf{0 , 3 6 0})$ menunjukan bahwa setiap terjadi kenaikan pada factor Supporting sebesar 1 satuan, maka kinerja akan berubah meningkat sebesar $\mathbf{0 , 3 6 0}$ satuan

e Koefisien regresi Delegating $\left(\mathrm{X}_{4}\right)(\mathbf{0 , 6 6 0})$ menunjukan bahwa setiap terjadi kenaikan pada factor Delegating sebesar 1 satuan, maka kinerja akan berubah meningkat sebesar $\mathbf{0 , 6 6 0}$ satuan.

Berdasarkan urutan kenaikan faktor tersebut maka urutan yang paling berpengaruh adalah variabel: 1) Delegating (0,660), kemudian 2) Supporting (0,360), selanjutnya 3) Selling
$(0,330)$, sedangkan variabel Directing hanya 0,059 kurang berpengaruh.

Apabila nilai $\mathrm{R}$ mendekati 1 maka secara bersama-sama dimensi-dimensi dari variabel bebas tersebut mempunyai hubungan positif yang cukup kuat. Selain itu dapat dijelaskan bahwa $R$. Square sebesar 0.845 (84.5\%) menerangkan bahwa kinerja pegawai Pusat Pengembangan SDM Aparatur KESDM berdasarkan dimensi variabel Directing (X1), Selling (X2), Supporting (X3), dan Delegating (X4) berpengaruh sebesar $84.5 \%$ sedangkan sisanya sebesar $15.5 \%$ menggambarkan variabel bebas lainnya yang tidak diamati dalam penelitian ini.

Berikut ini juga disampaikan resume hasil tanggapan responden terhadap masing-masing gaya kepemimpinan situasional dan kinerja pegawai sebagai berikut:

a Pada 9 indikator yang ditanyakan dari dimensi Directing (X1), hasilnya $37,4 \%$ responden menyatakan netral, kemudian $2,7 \%$ responden menyatakan sangat setuju, $27,8 \%$ responden menyatakan setuju, dan $21,5 \%$ responden menyatakan tidak setuju serta $9,6 \%$ sangat tidak setuju untuk gaya kepemimpinan Direktif atau instruktif.

b. Pada 8 indikator yang ditanyakan dari dimensi Selling (X2), hasilnya 5,4\% sangat setuju, $39,6 \%$ responden menyatakan setuju, 33,8\% responden menyatakan netral, dan $13,3 \%$ responden menyatakan tidak setuju dan $7,9 \%$ responden menyatakan sangat tidak setuju terhadap gaya kepemimpinan selling.

c. Pada 10 indikator yang ditanyakan dari dimensi Supporting (X3), hasilnya 4\% responden menyatakan sangat setuju, 39,7\% responden menyatakan setuju dan $36,7 \%$ responden menyatakan netral, dan $13 \%$ tidak setuju serta $6,7 \%$ sangat tidak setuju terhadap gaya kepemimpinan supporting atau partisipasif.

d. Pada 8 indikator yang ditanyakan dari dimensi Delegating (X4), hasilnya $3,8 \%$ responden menyatakan sangat setuju, $35 \%$ responden menyatakan setuju, 33\% responden menyatakan netral dan $21,7 \%$ menyatakan tidak setuju, serta $5,8 \%$ sangat tidak setuju terhadap gaya kepemimpinan Delegatif.

e. Pada 7 indikator yang ditanyakan dari variabel Kinerja (Y), hasilnya $13 \%$ responden menyatakan sangat setuju, 49,6\% responden menyatakan setuju dan $24,8 \%$ responden 
Roni Rahmat Nugraha : Peranan Gaya Kepemimpinan Situasional Dalam Meningkatkan Kinerja Pegawai Pusat Pengembangan Sumber Daya Manusia Aparatur (PPSDMA)

menyatakan netral dan $10,7 \%$ menyatakan tidak setuju, serta $1,9 \%$ sangat tidak setuju .

\section{KESIMPULAN DAN SARAN Kesimpulan}

Berdasarkan jawaban responden, analisis hipotesis serta pembuktiannya dapat ditarik kesimpulan bahwa:

1. Gaya kepemimpinan situasional baik Selling, Participating, dan Delegating dapat dikatakan berpengaruh signifikan terhadap kinerja pegawai PPSDM Aparatur.

2. Hampir semua gaya kepemimpinan situasional dominan berpengaruh terhadap kinerja pegawai, terutama gaya kepemimpinan Delegating, Supporting dan Selling, sedangkan gaya kepemimpinan Directing kurang berpengaruh. Berdasarkan urutan kenaikan faktor, yang paling berpengaruh adalah dimensi variabel : 1) Delegating $(0,660)$, kemudian 2) Supporting (0,360), selanjutnya 3) Selling (0,330), sedangkan dimensi variabel Directing hanya 0,059 kurang berpengaruh.

\section{Saran}

Berdasarkan hasil penelitian terbatas ini dapat diusulkan beberapa saran diantaranya:

1. Para pimpinan yang menjabat di PPSDM Aparatur KESDM dapat mempertimbangkan gaya kepemimpinannya pada faktor Directing, Gaya ini sangat tepat apabila dihadapkan dengan tugas yang rumit dan pegawai yang belum memiliki pengalaman dan motivasi untuk mengerjakan tugas tersebut. Dalam proses pengambilan keputusan, pemimpin memberikan aturan-aturan dan proses yang detil kepada bawahan. Pelaksanaan dilapangan harus menyesuaikan dengan detil yang sudah dikerjakan.

2. Pada gaya kepemimpinan yang dominan dominan mempengaruhi kinerja pegawai pada PPSDM Aparatur, seperti Delegating, Supporting, dan Selling, para pimpinan harus memperhatikan variabel tersebut. Gaya Selling dan Delegating akan berjalan dengan baik apabila staf atau bawahan sepenuhnya telah paham dan efisien dalam pekerjaan, sehingga pemimpin dapat melepas mereka menjalankan tugas atau pekerjaan itu atas kemampuan dan inisiatif sendiri.

3. Bagi peneliti yang tertarik dengan tema yang sama, selanjutnya bisa dikembangkan dengan menambah jumlah data yang diteliti dan variabel lain yang berkaitan dengan Kinerja Pegawai, sehingga hasil yang diperoleh lebih akurat dan mempunyai manfaat yang besar.

\section{DAFTAR PUSTAKA}

Bernadine P. Wirjana, 2005, Kepemimpinan Dasar-dasar dan Pengembangan, Andi Off set, Yogyakarta.

Campling, John, David Poole, Retha Wiesner, \& John R. Schermerhorn. Management, New York: John Wiley \& Sons Australia, Ltd, 2002.

Cunningham, William G, \& Paula A. Cordeiro. Educational Leadership, New York: Pearson Education, Inc., 2003.

Donni Juni Priansa, S.Pd., S.E., M.M. dan Dr. H. Suwatno, 2011, Manajemen SDM Dalam Organisasi Publik dan Bisnis, Alfabeta, Bandung.

Edwin B. Flippo, 2002, Manajemen Personalia, Edisi 6, Erlangga, Jakarta.

Edy Sutrisna, M, S.I, 2011, Sumber Daya Manusia, Edisi 3, Kencana Prenada Media Grup, Jakarta.

Gary Yulk, 2004, Kepemimpinan Dalam Organisasi, PT. Indeks, Jakarta.

Ghozali, Imam, Prof. Dr., M.Com, Akt., 2013, Aplikasi Analisis Multivariate dengan Program IBM SPSS 23. Badan Penerbit Universitas Diponegoro, Semarang.

Handoko, Hani, 2000, Manajemen Personalia dan Sumber Daya Manusia, BPFE UGM, Yogyakarta.

Hersey, Paul, \& Ken Blanchard, 1996. Manajemen Perilaku Organisasi, Pendayagunaan Sumber Daya Manusia, Edisi ke 4, Bahasa Indonesia, Jakarta: Erlangga

Khairizah, Astria, dkk. Tanpa tahun. Pengaruh Gaya Kepemimpinan Terhadap Kinerja Karyawan. Jurnal Administrasi Publik (JAP), Vol. 3, No. 7. Diambil dari https://media.neliti.com/media/publications/82330-IDpengaruh-gaya-kepemimpinan-terhadap...

M. S. P. Hasibuan, 2007, Manajemen SDM, Edisi Revisi PT. Bumi Aksara, Jakarta.

Mardalis, A \& Setiawan, E. (2015). Pengaruh Gaya Kepemimpinan dan Komitmen Organisasi Terhadap Disiplin Kerja Dengan Kepuasan Kerja Sebagai Variabel Intervening. Jurnal Manajemen Sumber Daya, 17(2). 6777.

Mas'ud, Fuad. (2004). Survai Diagnosis Organisasional, Konsep \& Aplikasi. Semarang: Badan Penerbit Universitas Diponegoro.

Mullins, Laurie J. Management and Organization Behavior, Edinburg, Harlow, Essex: Prentice Hall, 2005.

Newstrom, John W, \& Keith Davis, Organizational Behavior, New York: McGraw-Hill, 2002.

Prasetya Irawan, 2002, Pengantar Manajemen Umum, Edisi 2, PT. Gunung Agung, Jakarta.

Pratama, Yofanda Budi. 2015. Skripsi: Pengaruh Motivasi Kerja Dan Lingkungan Kerja Terhadap Kinerja Pegawai Pada Perusahaan Daerah Air Minum (Pdam) Kabupaten Sleman. Universitas Negeri Yogyakarta.

Rencana Strategis Pusat Pengembangan SDM Aparatur BPSDM ESDM tahun 2016-2019, 2016. Pusat Pengembangan SDM Aparatur BPSDM ESDM.

Rivai, Veithzal, 2004, Manajemen Sumber Daya Manusia Untuk Instansi atau organisasi, Rajawali Pers, Jakarta.

Roadmap PPSDM Aparatur 2016-2025. 2016. Pusat Pengembangan SDM Aparatur BPSDM ESDM. 
Roni Rahmat Nugraha : Peranan Gaya Kepemimpinan Situasional Dalam Meningkatkan Kinerja Pegawai Pusat Pengembangan Sumber Daya Manusia Aparatur (PPSDMA)

Siagian, Sondang P. 2006. Manajemen Sumber Daya Manusia. Jakarta: Penerbit Bumi Aksara.

Robbin, Stephen P. dan Timothy A. Judge. 2015. Perilaku Organisasi, Edisi Bahasa Indonesia, edisi 16. Penerbit Salemba, Jakarta

Sugiyono, 2005, Statistik Untuk Penelitian, Alfabeta, Jakarta. Suryani. Tanpa tahun. Pengaruh Gaya Kepemimpinan Terhadap Kinerja Pegawai Cv. Indah Mandiri Jaya Bandar Lampung. Diambil dari https://media.neliti.com/media/publications/56586-IDpengaruh-gaya-kepemimpinan-terhadap-kine.pdf tanggal 12 November 2017.

Syah, Muh. Addin. 2017. Pengaruh Gaya Kepemimpinan Situasional dan Komunikasi Organisasi Terhadap Kinerja Pegawai (Studi Eksplanatif Kuantitatif Pada Mojosongo). Universitas Muhammadiyah Surakarta.
Thoha, Miftah. 2013, Kepemimpinan Dalam Manajemen, Cetakan ke-17, PT. Raja Grafindo Persada, Jakarta.

Ulya, M. Z. (2015). Gaya Kepemimpinan Situasional Dan Pengaruhnya Terhadap Kinerja Pegawai (Studi Pada: PT. Telkom Indonesia, Tbk. Malang). Jurnal Ilmiah FEB, 3(1). Diambil dari http://jimfeb.ub.ac.id/index.php/jimfeb/article/view/149 4

Yuniawan, A, \& Putra, S. B. (2015). Pengaruh Gaya Kepemimpinan Situasional dan Lingkungan Kerja Terhadap Kinerja Pegawai dengan Motivasi Kerja sebagai Variabel Intervening (Studi Pada PT Bank OCBC NISP Tbk. KCP Bekasi). Journal of Management ,4(1),1-13. Diambil dari http://ejournals1.undip.ac.id/index.php/dbr 